\title{
POZITÍVNY ZÁVÄZOK SLOVENSKEJ REPUBLIKY VO VZŤAHU K ZÁKLADNÝM PRÁVAM A SLOBODÁM A ČL. 51 ODS. 1 ÚSTAVY SLOVENSKEJ REPUBLIKY
}

\author{
FERDINAND KORN
}

\begin{abstract}
The positive commitment of the Slovak Republic in the relation to the fundamental rights and freedoms and the Article 51 Section 1 of the Constitution of the Slovak Republic

The authors presents institute of a positive commitment of the Slovak Republic which enables the actors of constitutional rights and freedoms to actually implement the most basic rights and freedoms, which are enforceable only within the limits which are appointed by the laws by Constitution authorized to carry them out. In the context of the decisions of the Constitutional Court of the Slovak Republic and the comparison and synthesis of the legal opinions of the Constitutional lawyers provides insight on the definition dimension of the positive commitment of the state and with the possible consideration pro futuro.
\end{abstract}

Keywords: Positive Commitment of the State; Basic Rights and Freedoms; Constitution; Law; State

Kl’účové slová: pozitívny záväzok štátu; základné práva a slobody; ústava; zákon; štát

DOI: $10.14712 / 23366478.2018 .44$

\section{ÚVOD}

Záväzok štátu, vyplývajúci z l’udskoprávnych noriem, má dvojaké obsahové naplnenie, ktoré je signifikantné v troch kvalitatívnych rovinách, vyjadrených pojmami: rešpektovat', chránit' a naplnit'. Rešpektovat' znamená zo strany štátu zdržat' sa akéhokol'vek konania voči priestoru základných práv a slobôd jednotlivca, čo predstavuje negatívny záväzok štátu a chránit’ a naplnit’ znamená zo strany štátu prijat' legislatívne, administratívne a d'alšie opatrenia, ktoré majú zabezpečit', že základné práva a slobody budú uplatnitel'né v najvyššej možnej miere, čo predstavuje pozitívny záväzok štátu. ${ }^{1}$

Základným záväzkom štátu je povinnost' zdržat' sa zásahov do základných práv (negatívny záväzok štátu), predovšetkým u negatívnych práv a slobôd. Nevyhutným predpokladom základných práv a slobôd je však povinnost' štátu niečo aktívne konat'.

1 SOMOROVÁ, L.: Ústavná úprava základných práv a slobôd a jej perspektívy. In: OROSZ, L. a kol.: Ústavný systém Slovenskej republiky (doterajši vývoj, aktuálny stav, perspektívy). UPJŠ, Košice, 2009, s. 168 a nasl. 
Povinnost' štátu aktívne pôsobit' $\mathrm{k}$ naplňovaniu hospodárskych a sociálnych práv je zrejmá. Avšak i d’alšie základné práva a slobody vyžadujú aktívnu spoluprácu štátnych orgánov (napr.volebné právo, právo na informácie). Vo väčšine ústavne garantovaných základných práv a slobôd má štát okrem negatívneho záväzku zdržat' sa zásahu do práv a slobôd aj záväzok pozitívny, napríklad povinnost' chránit' jednotlivcovo základné právo a to jednak vytvorením legislatívneho rámca, jednak poskytnutím efektívnej súdnej ochrany. ${ }^{2}$ V. Šimíček označuje exitenciu legislatívnych procesných záruk ochrany základných práv a slobôd (najmä $\mathrm{v}$ zmysle piatej hlavy LZPS) za konkrétny princíp materiálneho právneho štátu v podmienkach ČR v spojení s čl. 1 ods. 1 Ústavy ČR. ${ }^{3}$

Nemecký právny teroretik R. Alexy rozlišuje tri typy práv na pozitívne konanie štátu:

- právo na ochranu - štát je povinný chránit život jednotlivca, jeho zdravie, majetok, dôstojnost' etc., teda nielen nerušit', ale aj aktívne chránit';

- právo na organizáciu a procedúru - štát nielen, že nesnie likvidovat právne inšitúty ako manželstvo, či vlastníctvo, ale je povinný vytvárat' pre jednotlivcov (občanov) inštitucionálne zázemie najrozličnejšieho druhu, aby občania mohli používat' svoje základné práva a slobody. Teda musia existovat' zákony, musia existovat' súdy a procesné poriadky, ktoré zabezpečeujú súdnu procedúru ako predpoklad práva na súdnu a inú právnu ochranu, musia existovat' univerzity ako organizácie, ktoré pomáhajú zabezpečeovat' právo na vzdelanie, musí existovat' inšitúcie a pravidlá tvorby štátne vôle, etc.;

- právo na plnenie $\mathrm{v}$ užšom slova zmysle, ktoré sa vzt’ahuje na sociálne práva. ${ }^{4}$

Uznanie katalogizovaných základných práv a slobôd tak, že zakladajú pozitívne konanie štátu, je významné posunutie vnímania l’udských práv oproti 19. storočiu. L'udskoprávne normy tak ovplyvňujú celý právny poriadok, trestné právo, občianske právo i d’alšie právne odvetvia, prežiarujú do celého právneho systému. Klasický vertikálny účinok základných práv a slobôd vo vzt’ahu štát - jednotlivec (práva občana - povinnosti štátu) je tak nepriamo rozšírený o horizontálny účinok základných práv a slobôd vo vzt'ahu občan - občan, porušenie hodnôt chránených l’udskoprávnymi normami medzi jednotlivcami navzájom môže byt' vnímané ako zásah do základných práv občana, pokial' štát hrubo zanedbal svoju povinnost' tieto hodnoty chránit', alebo pokial štátne orgány (všeobecný súd) dokonca súkromnoprávnenu konaniu porušujúcemu uvedené hodnoty poskytuje právnu ochranu. ${ }^{5}$

Ústava Slovenskej republiky patrí k ústavám, ktoré odkazujú na úpravu časti vymedzených základných práv a slobôd na zákony. Preto pre jej uplatňovanie a výklad je dôležité, či ústavodarca zaviazal zákonodarcu na normotvornú činnost', z ktorej vzídu zákony, umožňujúce subjektom ústavných práv a slobôd, aby mohli reálne uplatňovat’ aj tie základné práva a slobody, ktorých sa môžu domáhat' len v medziach, ktoré usta-

2 WINTR, J.: Principy českého ústavniho práva. 3. vyd., Vydavatelství a nakladatelství Aleš Čeněk, Plzeň, 2015, s. 143.

3 ŠIMÍČEK, V.: Komentář k čl. 1 ods. 1 Ústavy ČR. In: ŠIMÍČEK, V. - SUCHÁNEK, R. a kol.: Ústava České republiky. Komentár. Linde, Praha, 2010, s. 28.

4 ALEXY, R.: Theorie der Grundrechte. 3. vyd., Frankfurt am Main, 1996, s. 405-471.

5 WINTR, J.: Principy českého ústavního práva, s. 144. 
noví zákon ústavou splnomocnený na ich vykonanie. ${ }^{6}$ I. Kanárik vo vzt’ahu k prijatiu zákonov, ktoré reálne umožňujú jednotlivcovi uplatňovanie ústavne vymedzených základných práv a slobôd, pracuje s pojmom „organický zákon“, ktorý definuje ako zákon, ktorého vydanie ústava nevyhnutne predpokladá, resp. ukladá. ${ }^{7}$ Absencia organického zákona, ktorý má na základe ústavného splnomocnenia regulovat' kompletne určitú oblast' spoločenských vzt’ahov, ergo určitú oblast' realizácie základných práv a slobôd, je legislatívnym opomenutím, ktoré predstavuje porušenie pozitívneho záväzku štátu a je v systéme objektívneho práva osobitným druhom právnej medzery. ${ }^{8}$ Hoci uvedená konštatácia je najčastejšie spojená s čl. 51 ods. 1 Ústavy Slovenskej republiky (d’alej len „ústavy“"), ktorý zakladá, že domáhat’ sa práv uvedených v čl. 35, 36, 37 ods. 4, č. 38 až 42 a čl. 44 až 46 tejto ústavy sa možno len v medziach zákonov, ktoré tieto ustanovenia vykonávajú, (kedže Ústavný súd Slovenskej republiky identifikoval čl. 51 ods. 1 ústavy ako ústavný základ pozitívneho záväzku Slovenskej republiky zabezpečit' v zákonoch základné práva a slobody priznané ústavou), ${ }^{9}$ pozitívny záväzok štátu má na základe rozhodnutí Ústavného súdu Slovenskej republiky širší pojmový rozmer a nemožno ho spájat' iba s výkonom základných práv a slobôd, taxatívne vymedzenými v čl. 51 ods. 1 ústavy.

\section{DEFINIČNÝ ROZMER POZITÍVNEHO ZÁVÄZKU ŠTÁTU}

Ústavný súd Slovenskej republiky potvrdil založenie pozitívneho záväzku štátu pri realizácii základných práv a slobôd na základe existencie dvoch východiskových prameňov:

- existencia pozitívneho záväzku štátu založeného prameňmi medzištátneho práva (II. ÚS 47/97),

- existencia pozitívneho záväzku štátu založeného vnútroštátnymi ustanoveniami danými Ústavou Slovenskej republiky (II. ÚS 8/96).

Na základe uvedeného smeruje pozitívny záväzok Slovenskej republiky pri prijatí opatrení k zabezpečeniu ochrany základných práv a slobôd:

- k všetkým základným právam a slobodám, zakotveným v Ústave Slovenskej republiky, v Dohovore o ochrane l'udských práv a základných slobôd, v Listine základných práv a slobôd, etc. (A),

- k základným právam a slobodám, ktoré sú vymedzené v čl. 51 ods. 1 ústavy (B). Ad A. Judikatúrou Ústavného súdu Slovenskej republiky sa do právneho poriadku Slovenskej republiky zaviedla doktrína pozitívneho záväzku štátu vo vzt'ahu k uplatneniu základných práv a slobôd. Uvedená doktrína vyplýva súčasne z Dohovoru o ochrane

6 DRGONEC, J.: Základné práva a slobody podla Ústavy Slovenskej republiky. Zväzok 1, MANZ, Bratislava, 1997, s. 57 a nasl.

7 KANÁRIK, I.: Legislatívna nečinnost' zákonodarného orgánu v právnom štáte (v rovine vnútroštátneho práva). In: Ústava Slovenskej republiky a jej uplatňovanie v legislativnej a právno-aplikačnej praxi. Košice, 2009, s. 10.

8 KANÁRIK, I.: Legislatívna nečinnost' zákonodarného orgánu v právnom štáte (v rovine vnútroštátneho práva), s. 6.

9 ČIČ, M. a kol.: Komentár k Ústave Slovenskej republiky. Eurokódex, 2012, s. 360. 
l’udských práv a základných slobôd (d’alej len „Dohovor“) i z judikatúry ústavných súdov iných európskych štátov. Ústavný súd sa vyslovil, že orgány Rady Európy uplatňujú Dohovor o ochrane l'udských práv a základných slobôd podl'a výkladu tak, že aj nečinnost' štátu, ktorá má za následok ignoráciu priznaných práv, možno pokladat' za formu porušenia Dohovoru o ochrane l'udských práv a základných slobôd. Pri určovaní, či pozitivny záväzok štátu existuje, Európsky súd pre l’udské práva berie do úvahy spravodlivú rovnováhu, ktorá sa má nastolit medzi verejným záujmom a záujmom jednotlivca. ${ }^{10}$ Pozitivny záväzok vyplývajúci aj z d'alšich medzinárodných zmlúv, ktoré ratifikovala a vyhlásila, alebo ktoré ratifikuje a vyhlási vo svojej zbierke zákonov Slovenská republika, táto musí plnit', pokial' voči nemu neuplatni výhradu. ${ }^{11}$

Podl’a čl. 2 ods. 2 Medzinárodného paktu o občianskych a politických právach: „Každý štát, ktorý je zmluvnou stranou paktu, sa zaväzuje, pokial' tak už neustanovujú existujúce zákonné alebo iné opatrenia, že podnikne nevyhnutné kroky v súlade so svojimi ústavnými postupmi a ustanoveniami tohto paktu, aby schválil také zákonodarné alebo iné opatrenia potrebné nato, aby sa uplatnili práva uznané v pakte.“

Podl'a čl. 2 ods. 1 Medzinárodného paktu o hospodárskych, sociálnych a kultúrnych právach: „Každý štát, ktorý je zmluvnou stranou paktu, sa zaväzuje podniknút’ pri maximálnom využití svojich zdrojov samostatne aj prostredníctvom medzinárodnej súčinnosti a spolupráce hospodárske a technické kroky na postupné dosiahnutie plného uskutočnenia práv uznaných $\mathrm{v}$ tomto pakte a to všetkými vhodnými prostriedkami, vrátane prijatia zákonných opatrení.“

Podla čl. 1 Dohovoru o ochrane l’udských práv a základných slobôd: „Vysoké zmluvné strany priznávajú každému, kto podlieha ich jurisdikcii, práva a slobody uvedené v Hlave I Dohovoru." V nadväznosti na d’alšie ustanovenia upravujúce jednotlivé práva sa toto znenie článku I interpretovalo tak, že štátom ukladá negatívny i pozitívny záväzok. Pozitívny záväzok je taký, podl'a ktorého štát musí konat', aby zabezpečil l'udské práva. V Dohovore je výslovne indikované množstvo pozitívnych záväzkov, rad d’alších odvodili orgány Rady Európy pri aplikácii Dohovoru ako implikované záväzky vyplývajúce z výkladu znenia Dohovoru. V Dohovore je napr. ustanovený záväzok chránit' zákonom právo na život (čl. 2 ods. 1), poskytnút' väzenské podmienky, ktoré nie sú „nel'udské“ (čl. 3), poskytnút súdy, právnu pomoc a prekladatel’ov v spojení s právom na spravodlivý proces (čl. 6) a uskutočnit' slobodné vol'by (čl. 3 Prvého protokolu). ${ }^{12}$

Normotvornú povinnost' štátov v Európskej únii ustanovuje čl. 189 ods. 3 Zmluvy o EHS. Podl'a tohto ustanovenia členské štáty prijmú všetky opatrenia nevyhnutné na dosiahnutie účelu sledovaného smernicou. V konaní pred Súdnym dvorom možno dosiahnut' rozhodnutie o porušení pozitívneho záväzku legislatívnou nečinnost'ou, Po prvý raz sa tak stalo v konaní Frankovich and others v. Italian Republic. ${ }^{13}$

Porušenie pozitívneho záväzku Slovenskej republiky k základnému právu jednotlivca na ochranu života bolo vyslovené v rozsudku Európskeho súdu pre l’udské práva

10 Rees Case. Publications of the Euroean Court of Human Rights. Series A: Judgements and Decisions. Köln-Berlin-Bonn-Munchen, Carl Heymanns Verlag KG, č. 108, s. 15, § 37.

11 II. ÚS 8/96. Zbierka nálezov a uznesení Ústavného súdu Slovenskej republiky 1996. Košice, s. 110-111.

12 DRGONEC, J.: Ochrana ústavnosti Ústavným súdom Slovenskej republiky. Polygrafické centrum. Bratislava, 2010, s. 241.

13 Joined Cases C-6/90 and C-9/90. Judgement of 19 november 1991. ECR, I-5364. 
vo veci: Case of Kontrová vs. Slovakia zo dňa 31. mája 2001 k st’ažnosti č. 7510/04. Súd vyslovil, že prvá veta článku 2 ods. 1 Dohovoru ukladá štátu nielen zdržat'sa úmyselného nezákonného pozbavenia života, ale tiež uskutočnit’ primerané kroky za účelom ochrany života osôb podliehajúcich jeho jurisdikcii. Súd d'alej konštatuje, že pri posudzovaní rozsahu takéhoto pozitívneho záväzku podl'a čl. 2 Dohovoru treba brat'do úvahy povinnost'zmluvných štátov zabezpečit'skutočnú a účinnú ochranu práv a slobôd, ktoré sú v ňom stanovené. ${ }^{14}$ Ked’že právo na život má svoje ústavné zakotvenie v čl. 15 Ústavy Slovenskej republiky, má sa za to, že pozitívny záväzok štátu v zmysle judikatúry Európskeho súdu pre l’udské práva i judikatúry Ústavného súdu Slovenskej republiky sa vzt’ahuje na všetky práva a slobody vymedzené v druhej hlave Ústavy Slovenskej republiky, nielen na základné práva a slobody zakotvené v čl. 51 ods. 1 ústavného textu. Ústavný súd Slovenskej republiky definuje d’alej pozitívny záväzok štátu vo svojom náleze II. ÚS 8/96 tak, že: „pozitívnym záväzkom sa chránia aj práva a slobody stanovené v Ústave Slovenskej republiky. Obsahom pozitívneho záväzku štátu vo vzt’ahu k právam a slobodám občana je povinnost' podnikat' opatrenia na ochranu práv, ktoré v ústave priznal občanovi, ale súčast'ou pozitivneho záväzku nie je povinnost' dosiahnut' výsledok, ktorý občan od štátu žiada. Pozitivny záväzok štátu urobit'opatrenia potrebné na zabezpečenie ochrany l'udských práv a základných slobôd priznaných Ústavou Slovenskej republiky a medzinárodnými zmluvami nemožno interpretovat' ako povinnost' orgánov štátnej moci urobit'opatrenia na ochranu týchto práv a slobôd aj v prípade, ak sa o ich ochranu poškodená osoba neuchádza. "15

Ad B. V zmysle čl. 51 ods. 1 ústavy sa výkonu niektorých základných práv a slobôd možno domáhat' len v medziach zákonov, ktoré ústavu vykonávajú. Čl. 51 ods. 1 ústavy je ústavným prameňom, ktorým sa ustanovuje osobitný ústavný režim taxatívne vypočítaných základných práv a slobôd . Ústavný súd Slovenskej republiky účel tohto ustanovenia hodnotil tak, že ústava článkom 51 ods. 1 zaručuje, že Slovenská republika príjme zákony ustanovujúce podmienky uplatnenia základných práv a slobôd, uvedených v článku 51 ods. 1 ústavy. Preto v prípade, ak ústava predpokladá na reálne uplatnenie určitého práva vydanie takéhoto zákona a Národná rada Slovenskej republiky svoju zákonodarnú povinnost' opomína, teda zákon neprijme, možno to považovat' za porušenie pozitívneho záväzku štátu podniknút' potrebné opatrenia na ochranu práv a slobôd. ${ }^{16}$ $\mathrm{Z}$ uvedeného plynie, že čl. 51 ods. 1 ústavy je vyjadrením jednak nevyhnutnosti bližšej konkretizácie práva a slobody, ktoré je uvedené v dotknutom ústavnom článku a jednak vyjadrením možnosti pre nositel'ov v čl. 51 ods. 1 ústavy vymedzených základných práv a slobôd domáhat' sa uvedených práv a slobôd len v medziach zákonov, ktoré uvedené ustanovenia vykonávajú.

J. Drgonec vyslovuje názor, že článkom 51 ods. 1 Ústavy Slovenskej republiky sa znižuje dostupnost’ taxatívne určených základných práv a slobôd pre jednotlivca. Každý sa podl’a uvedeného článku môže niektorých základných práv a slobôd domáhat iba v medziach zákona. Ak zákon, ktorý príslušné základné právo alebo slobodu vykonáva, neza-

14 DRGONEC, J.: Ústava Slovenskej republiky. Komentár. 3. vyd., Heuréka, 2012, s. 314 a nasl.

15 BRÖSTL, A.: Ústavné právo Slovenskej republiky. Vydavatelství a nakladatelství Aleš Čenek, Plzeň 2010, s. 95 .

16 BRÖSTL, A.: Ústavné právo Slovenskej republiky, s. 96. 
kladá právny nárok na domáhanie sa základného práva v niektorých okolnostiach, alebo ak nezakladá právny nárok na domáhanie sa základného práva skupinou osôb, následkom toho je, že aj v takom prípade sa základné právo alebo sloboda priznáva ako ústavné právo, ale v konaní pred orgánom výkonnej moci alebo súdnej moci nemožno dosiahnut' vydanie individuálneho aktu aplikácie práva v prospech konkrétnej osoby. ${ }^{17} \mathrm{~J}$. Drgonec považuje základné práva a slobody, vymedzené v čl. 51 ods. 1 ústavy za tzv. qvaziústavné práva, $\mathrm{v}$ názorovom súhlase s nemeckým právnym teoretikom C. Schmittom, ktorý vo svojej požiadavke na zistenie l'udských práv konštatuje: „Skutočné základné práva sú absolútne $\mathrm{v}$ tom zmysle, že nie sú vykonávané $\mathrm{v}$ medziach zákonov, ich obsah teda nevyplýva zo zákona. Zákonné obmedzenie je naopak výnimkou, z čoho vyplýva, že táto výnimka musí byt' principiálne obmedzená, určitel'ná a regulovaná.“18

Podla I. Kanárika nevydanie organického zákona v prípade čl. 51 ods. 1 ústavy môže byt' výsledkom rôznych mimoprávnych situácií a teda príčinou legislatívneho opomenutia môže byt' aktuálny politický stav v spoločnosti, medzinárodná situácia, zlý stav v ekonomike, ktorý neumožňuje finančné vykrytie pripravovanej právnej úpravy. Do úvahy musí byt' preto vzatý prípadný nedostatok „všeobecnej politickej vôle“ v spoločnosti, politické rozpory vo vládnucej koalícii a pod. ${ }^{19}$

Čl. 51 ods. 1 ústavy predstavuje ústavný spôsob zakotvenia prevažne hospodárskych, sociálnych a kultúrnych práv, pričom sa má za to, že vymedzenie uvedených práv je ponechávané na zákonodarcovi, aby tento zakotvil zákonné podmienky na ich realizáciu. Tento spôsob zakotvenia sa tradične odôvodňuje tým, že hospodárske, sociálne a kultúrne práva sú výrazne závislé od úspešnosti ekonomického a sociálneho rozvoja štátu.

K romachu hospodárskch a sociálnych práv ako práv druhej generácie, na rozdiel od základných l’udských práv a politických práv, došlo až po druhej svetovej vojne. Pri rozlišovaní sociálnych práv od liberálnych slobôd býva spravidla poukazované na odlišnú povahu korešpondujúcej povinnosti štátu. Sociálne práva sú, ako všetky základné práva a slobody, verejnými subjektívnymi právami jednotlivca voči ich garantovi, štátu, ktorým komplementárne zodpovedajú určité povinnosti štátu voči nositel'ovi dotknutých práv, voči jednotlivcovi. Zatial' čo u základných l'udských a politických práv a slobôd prevažuje povinnost' štátu zdržat' sa určitého konania do individuálnej sféry chránenej základným právom, u sociálnych práv je výrazne v popredí povinnost’ štátu konat', predovšetkým zaistit' $v$ prípade potreby nositel'ovi uvedeného práva určité plnenie alebo službu. ${ }^{20}$

Textácia čl. 51 ods.1 Ústavy SR o tom, že sociálnych práv sa možno domáhat' len v medziach zákonov, ktoré ich vykonávajú, znamená, že hospodárska politika štátu sa odvodzuje od záujmu nositel’a štátnej moci, ktorý vzíde z parlamentných volieb ako ich vít’az, čo znamená príklon bud' $\mathrm{k}$ intervencionistickej hospodárskej politike, ergo aktív-

17 DRGONEC, J.: Ústava Slovenskej republiky. Komentár, s. 864 a nasl.

18 SCHMITT, C.: Verfassungelhre, 1928, s. 166, cit.: ONDŘEJEK, P.: Princip proporcionality a jeho role při inetrpretaci základních práv a svobod. Nakladadatelství Leges, Praha, 2012, s. 50.

19 KANÁRIK, I.: Legislatívna nečinnost' zákonodarného orgánu v právnom štáte (v rovine vnútroštátneho práva). In: Zbornik príspevkov z vedeckého seminára Ústava Slovenskej republiky a jej uplatňovanie v legislatívnej a právno-aplikačnej praxi, s. 11.

20 WINTR, J.: Principy českého ústavního práva, s. 174. 
nej tvorbe štátnej moci v hospodárstve štátu, alebo príklon k neoliberálnej hospodárskej politike, ergo s minimálnym štátnym zásahom do trhových vzt’ahoch $\mathrm{v}$ hospodárstve štátu. Bolo by preto ústavne rigidným stavom, ak by konkrétny zákon, upravujúci neoliberálnu alebo intevencionistickú predstavu vít’aza volieb o hospodárskej politike štátu, nemohol konkrétny nositel' štátnej moci prostredníctvom objektívneho práva realizovat' prijímaním jednoduchých zákonov, absolutnou vačšinou, ale napr. ústavnou väčšinou, vzhl'adom na to, že by rovnako esenciálne jadro ako aj vonkajšie forum základného hospodárskeho a sociálneho práva bolo garantované ústavne. Tým, že je forum externum (vonkajšie forum), teda výkon základného hospodárskeho a sociálneho práva, prenesený ex constitutione na zákon, nastáva stav, že hospodárske, sociálne a kultúrne práva sú $\mathrm{v}$ právami ústavnými, pretože ich esenciáne jadro (forum internum) je vymedzené $\mathrm{v}$ ústave a zároveň ich garant a adresát, teda štát (konkrétny nositel’ štátnej moci) môže flexibilným prijímaním zákonov v parlamente jednak pretavit' svoju predstavu o hospodárskej politike v štáte a jednak pretavit' vôlu voliča vít’azných strán vo vol'bách (teda účasti občana na výkone štátnej moci) o budúcej neoliberálnej alebo intervencionistickej politike štátu v priestore jeho hospodárstva a to práve zákonnou úpravou výkonu (forum externum) uvedených základných práv a slobôd s troma zaväzujúcim ústavnými obmedzením, ktorými sú:

- zachovanie esenciálneho jadra základného práva vymedzeného v ústave (napr. Ústavný súd ČR v náleze Pl. ÚS 2/08, č. 166/2008 Sb., bod 56 zakladá, že: ,zakotvenie existencie socálnych práv v Listine (esenciálneho jadra) znamená, že pri zákonnej úprave ich výkonu musí byt' zachovaný minimálny štandard týchto sociálnych práv“);

- pri zásahu do esenciálneho jadra vymedzeného sociálneho práva dbat' na podstatu a zmysel takéhoto zásahu a na ústavný imperatív, že daný zásah môže byt' použitý iba na stanovený účel a ciel' a že sa musí vzt’ahovat' na všetky prípady, ktoré splňajú stanovené podmienky (čl. 51 ods. 1 ústavy SR je podl'a I. Palúša považovaný za jeden z prameňov možnosti obmedzenia základného práva a slobody, vymedzeného $\mathrm{v}$ ústave v čl. 13 ods. 2,3 a 4); ${ }^{21}$

- vylúčenie negácie, alebo ignorovania sociálneho a ekologicky orientovaného charakteru hospodárstva štátu, daných Ústavou SR v čl. 55.

Ústavný súd Českej republiky sa vo svojom náleze sp. zn. Pl. ÚS 54/10, č. 186/2012 Sb. vyslovil, že pri zásahu do ústavne garantovaných hospodárskych a sociálnych práv zo strany zákonodarcu a následnej aplikácii testu proporcionaliy ústaným súdom je nevyhnutné rě́pektovat pomerne rozsiahlu diskrečnost' zákonodarcu pri zákonnej úprave predmetných ústavných práv jednotlivca, ktorá však nesmie prerást' do prípadných excesov (tzv. mäkší test proprorcionality - test rozumnosti). ${ }^{22}$

Takto definovaný čl. 51 ods. 1 Ústavy SR teda neznamená len prostú povinnost' štátu prijat' organický zákon na vykonanie základných práv a slobôd taxatívne vymedzených v čl. 51 ods. 1 ústavy, ale naplnenie pozitívneho záväzku štátu je zároveň:

21 PALÚŠ, I. - SOMOROVÁ, L.: Štátne právo Slovenskej republiky. UPJŠ, Právnická fakulta, Košice, 2011, s. 148 a nasl.

22 WINTR, J.: Principy českého ústavního práva, s. 135. 
- odrazom možnosti občana ako pôvodcu štátnej moci podiel'at' sa na výkone štátnej moci, pretože prijímaním zákonov upravujúcich výkon hopodárskych a sociálnych práv sa prejavuje väčšinová vôl'a voličov po parlamentných vol'bách v oblasti hospodárskej a sociálnej politiky štátu (zákony upravujúce pracovnoprávne vzt’ahy, normy práva sociálneho zabezpečenia, daňového práva etc., legalita je zaručená prijímaním sociálnych zákonov, legitimita je odrazom účasti občanov vo vol’bách);

- odrazom vôle nositel’a štátnej moci (politickej strany, ktorej hlavná úloha je úloha vládnúca) pri realizácii jeho hospodárskej a sociálnej politiky vzhl’adom na jeho neoliberálnu alebo intervencionistickú podstatu a zameranie;

- je naplnením princípu právnej istoty $\mathrm{v}$ zmysle jasnosti a určitosti objektívneho práva pre jednotlivca $\mathrm{v}$ zmysle ústavnej definicie právneho štátu a v zmysle ústavného princípu podla čl. 2 ods. 3 Ústavy Slovenskej republiky;

- je naplnením princípu procesných záruk ochrany základných práv a slobôd;

- je naplnením príncípu právnej istoty pre výkon jeho hospodárskych a sociálnych preáv taxatívne vymedzených $\mathrm{v}$ čl. 51 ods. 1 ústavy;

- predstavuje normatívne vyváženie neoliberálneho hladiska trhového charakteru hospodárstva štátu a sociálneho hl'adiska charakteru toho istého hospodárstva v rámci jednotného ústavného definičného pojmu hospodárstva sštátu;

- je naplnením predpokladu plynúceho z ústavných článkov, ktoré priamo predpokladajú podrobnejšiu vykonávaciu zákonnú úpravu o organizácii a fungovaní štátu;

- je naplnením priamej ústavnej povinnosti zákonodarcu zákonnú úpravu prijat'.

L. Somorová konštatuje, že sa postupne stále viac objavujú myšlienky, podporujúce rovnakú dôležitost' a hodnotu daných práv vo vzt’ahu k ostatným základným právam a slobodám, upraveným v ústavnom texte. V úvode článku spomínaný trojzáväzok štátu, vyplývajúci z kvality ludskoprávnych noriem, teda záväzok štátu rešpektovat', chránit' a naplnit' priestor základných práv a slobôd jednotlivca, sa totiž vzt’ahuje na všetky základné práva a slobody, navyše ak pozitívny záväzok štátu neplynie iba z uvedenej doktrinálnej (teoretickej) úvahy, ale i samotnej judikatúry Ústavného súdu Slovenskej republiky, podl'a ktorého pozitívny záväzok Slovenskej republiky plynie i z Dohovoru o ochrane l'udských práv a základných slobôd (napr. PL ÚS 13/97) alebo z Dohovoru o právach diet'at’a (II. ÚS 47/97). ${ }^{23}$

Okrem vyššie uvedeného analytického pohladu na definičnú podstatu existencie pozitívneho záväzku štátu, možno porušenie pozitívneho záväzku štátu definovat’ i z hl’adiska realizácie objektívneho práva ako:

- absenciu legislatívnej povinnosti štátu prijat' zákony, umožňujúce ochranu základných práv a slobôd (napr. čl. 51 ods. 1 ústavy ) - fáza tvorby práva (absencia danej povinnosti je porušením pozitívneho záväzku štátu);

- absenciu zo strany štátu uskutočnit’ primerané kroky za účelom ochrany základných práv a slobôd osôb, podliehajúcich jeho jurisdikcii (napr.spomínaný rozsudok Európskeho súdu pre l’udské práva vo veci: Case of Kontrová vs. Slovakia zo dňa

23 SOMOROVÁ, L.: Ústavná úprava základných práv a slobôd a jej perspektívy. In: OROSZ, L. a kol.: Ústavný systém Slovenskej republiky (doterajší vývoj, aktuálny stav, perspektívy). UPJŠ, Košice, 2009, s. 168 a nasl. 
31. mája 2001 k st’ažnosti č. 7510/04) - fáza aplikácie práva. (Ústavný súd Slovenskej republiky rozhodol, že nečinnost' Ministerstva zahraničných veci Slovenskej republiky bola porušením pozitívneho záväzku štátu pri zabezpečovaní základného práva občana na slobodný vstup na územie Slovenskej republiky podl’a čl. 23 ods. 4 prvá veta ústavy a podl'a čl. 12 ods. 4 Medzinárodného paktu o občianskych a politických právach (II. ÚS 8/96). Vo fáze aplikácie práva musia pozitívny záväzok plnit' aj všeobecné súdy (I. ÚS 4/02).) ${ }^{24}$

\section{JUDICIÁLNE VÝSTUPY A DOKTRINÁLNE ZÁVERY O LEGISLATÍVNEJ NEČINNOSTI A LEGISLATIIVNOM OPOMENUTÍ}

Ústavný súd Slovenskej republiky v súvislosti s koncepciou pozitívneho záväzku štátu položil dôraz na rozlíšenie medzi legislatívnym opomenutím a legislatívnou nečinnost'ou, pričom zvýraznil, že iba legislatívne opomenutie môže byt' nesplnením pozitívneho záväzku: „Ústavný súd vychádzajúc z modernej konstitucionalistiky rozlišuje medzi legislatívnym opomenutím a legislatívnou nečinnost'ou. Legislativna nečinnost' (legislative non-action, nepravá medzera v práve) znamená, že daná oblast' spoločenských vzt'ahov je zákonodarcom vedome ponechaná úplne mimo právnu reguláciu. Tento druh medzery spravidla nebýva objektom skúmania ústavných súdov $v$ rámci abstraktnej kontroly.

Legislativne opomenutie (legislative omission) je naopak stavom, ked' zákonodarca pozitivine upravujúc určitú oblast'spoločenských vzt'ahov opomenul niektoré významné prvky tejto právnej úpravy. Zákonodarca teda pri legislatívnom opomenutí reguluje určitú oblast' nekompletne či fragmentálne, opominajúc právny komponent, ktorý je želatelný z hl'adiska integrity daného inštitútu, resp. ústavnosti (čiastočná nečinnost' zákonodarcu). Ústavné súdy za určitých okolností riešia situáciu legislatívneho opomenutia bud' derogáciou z pozície negativneho zákonodarcu, alebo ústavne konformným výkladom. V̌seobecný súd nesmie pri rozhodovani odmietnut' spravodlivost' ani v prípade nepravej medzery v práve. Ústavný súd však v rámci abstraktnej kontroly môže konštatovat', že ide o legislatívne opomenutia, eventuálne ho riešit derogačným apelom na zákonodarcu. Môže však taktiež, využijúc aj perspektivu všeobecného súdu aplikujúceho dané ustanovenie, vykonat' záväzný, ústavne konformný výklad. " (PL. ÚS 23/2005)25

Doktrinálny pohl'ad na pojmy legislatívna nečinnost' a legislatívne opomentutie poskytuje názor J. Tryznu a V. Šimíčka, ktorý dotknuté pojmy vníma skôr synonymicky. ${ }^{26}$ Podl'a J. Tryznu výrazom „legislatívna nečinnost"“ nemožno označit' iba samotnú skutočnost', že zákonodarný orgán neplní svoju úlohu spočívajúcu v prijímaní zákonov ako takých, ale za „legislatívnu nečinnost“" možno považovat' i stav, ked' zákonodarný

24 ČIČ, M. a kol.: Komentár k Ústave Slovenskej republiky, s. 364.

25 DRGONEC, J.: Komentár k čl. 51. In: ČIČ, M. a kol.: Komentár k Ústave Slovenskej republiky, s. 362.

26 ŠIMÍČEK, V.: Opomenutí zákonodarce jako porušení základních práv. In.: ŠIMÍČEK, V. - DANČ́́K, B. (eds.): Deset let Listiny základnich práv a slobod v právním řádu České republiky a Slovenskej republiky. Masarykova univerzita, Mezinárodní politologický ústav, Brno, 2001. 
orgán neprijme právnu úpravu, ktorú je povinný z určitého konkrétneho dôvodu prijat', bez toho, aby sa d'alej skúmali dôvody takéhoto neprijatia (politické, ekonomické, legislatívne etc.). Podla V.Šimíčka sa namiesto pojmu „legislatívna nečinnost"“ niekedy použiva pojem „legislatívne opomenutie“, podl’a J. Tryznu je takéto označenie potrebné považovat' za užšie, pretože navodzuje dojem, že ide o úmyslenú nečinnost' zákonodarného zboru. J. Tryzna pri tomto závere vychádza z idei racionálneho zákonodarcu, ktorá predpokladá, že zákonodarca sa úmyselných pochybení nedopúšs’a a že prípadné nedostatky v legislatíve možno pričítat' nedoceneniu určitých aspektov okruhu spoločenských vzt’ahov zákonodarcom regulovaných. J. Tryzna spája pojem „legislatívna nečinnost" v kontexte s pojmom „opomenutie zákonodarcu“ pre prípad nedostatočnej zákonnej úpravy, ktorá je markantná najčastejšie v porušení požiadavky rovnosti v najširšom slova zmysle, no podl'a neho medzi pojmami legislatívna nečinnost', opomentutie zákonodarcu a nepravá medzera možno dat' $\mathrm{v}$ podstate rovnítko.

Vychádzajúc z nálezov Ústavného súdu ČR sp. zn. PL. ÚS 3/06 alebo sp. zn. PL. ÚS 20/04 i doktrinálnych záverov možno ustálit' existenciu nedostatočnej zákonnej úpravy, ktorá je bud' relatívna alebo absolútna (podl’a J. Tryznu ,relatívna alebo absolútna legislatívna nečinnost"“). Relatívna nedostatočná právna úprava je legislatívny stav, kedy riešenie určitej právne relevantnej situácie možno nájst' aplikáciou a výkladom práva. $\mathrm{V}$ prípade neprekonatel'ných medzier $\mathrm{v}$ právnom poriadku (pomerne zriedkavý stav) hovoríme o absolútnej nemožnosti nájst' riešenie určite právne relevantnej situácie.

J. Tryzna poukazuje na skutočnost', že väčšina ústavne vymedzených základných práv a slobôd je priamo vymáhatel'ná ex contitutione bez ohl'adu na to, či je bližšie upravená zákonom. („Podrobnosti upraví zákon“). Tento postulát sa však nezt’ahuje na základné práva vymedzené $\mathrm{v}$ čl. 51 ods. 1 ústavy a to $\mathrm{z}$ dôvodu, že v zmysle textácie uvedenej ústavnej úpravy je existencia zákonnej úpravy predpokladom pre to, aby tam vymedzené základné práva boli vymáhatel’né. Vychádzajúc z uvedených konštatácii prezentuje J. Tryzna definičný záver o legislatívnej nečinnosti a to $\mathrm{v}$ tom zmysle, že o legislatívnej nečinnosti možno v negatívnom význame uvedeného pojmu hovorit' v prípadoch, ked’ ústavné normy priamo predpokladajú podrobnejšiu vykonávaciu zákonnú úpravu (o organizácii a fungovaní štátu, o niektorých ustanoveniach o základných právych a slobodách) - hovoríme o priamej povinnosti zákonodarcu zákonnú úpravu prijat'.

Pokial' sa jedná o základné práva a slobody, ktoré sú z ústavy priamo aplikovatel’né, v týchto prípadoch záver o legislatívnej nečinnosti platí spravidla iba na základe úvah de lege ferenda a to najčastejšie $\mathrm{v}$ prípadoch, ked' sa jednotlivec dovoláva svojho základného práva a slobody voči inému jednotlivcovi, ked’že sa má za to, že vo väčšine prípadov je pre uplatňovanie si subjektívneho práva postačujúca ústavná úprava, pretože táto poskytuje dostatočný podklad pre rozhodovanie v konkrétnych prípadoch. ${ }^{27}$

27 GERLOCH, A. a kol.: Teorie a praxe tvorby práva. ASPI, Praha, 2008, s. 63 a nasl. 


\section{ZÁVER}

Podstata materiálneho právneho štátu spočíva $\mathrm{v}$ tom, že subjekty všetkých právnych vzt’ahov, súkromnoprávnych aj verejnoprávnych, sa správajú v súlade s platným právnym poriadkom. Prvoradým predpokladom takéhoto stavu je existencia právnej úpravy, ustanovujúcej práva a povinnosti subjektov dotknutých ústavou. Ak zlyhá zákonodarca, alebo ak orgán výkonnej moci nevydá vykonávací predpis, ktorý má na základe zmocnenia od zákonodarbého orgánu vydat', narúša sa mechanizmus správania subjektov práva alebo sa dokonca vôbec nedá uviest' do chodu. V právnom štáte vznikne trhlina skôr, ako právo začalo pôsobit'. V záujme odvrátenia alebo aspoň oslabenia takejto hrozby sa vytvárajú medzinárodné a vnútroštátne prostriedky určené na to, aby orgány štátu právo tvorili, aby schval'ovali zákony upravujúce zvlášt’ závažné vzt'ahy a právne postavenie účastníkov týchto vzt'ahov. Zásadný význam má povinnost' zákonodarnej moci vydávat' zákony, ktorú v jej prípade nečinnosti ukladá súdna moc v osobitnom konaní, slúžiacom na zistenie, či neexistencia zákonnej úpravy predstavuje protiprávny stav. ${ }^{28}$

Pramene ochrany základných práv a slobôd tvorí v európskom právnom priestore vo svoje komplexnosti tzv. štrasburský systém ochrany l’udských práv. Vd’aka nemu je právo l'udských práv v Európe silne harmonizované. V európskych štátoch je tak de facto vylúčené správne chápat' a používat' základné práva a slobody bez znalosti Európskej zmluvy a judikatúry ESL'P. ${ }^{29}$

Slovenská republika je členom EU, platí čl. 1 ods. 2 ústavy a čl. 7 ústavy, ktoré zakladajú prednost' primárneho práva EU pred zákonmi a zároveň prednost' právne záväzných aktov EU pred zákonmi Slovenskej republiky. Ak teda výkon základných hospodárskych a sociálnych práv je upravený zákonmi SR a ten istý priestor spoločenských vzt’ahov je upravený normami primárneho alebo sekundárneho práva EU, alebo nie je vnútroštátnym právon upravený, platí právny poriadok EU v zmysle princípu prednosti práva EU, alebo platí implementačná povinnost' v zmysle priameho alebo nepriameho účinku sekundárneho práva EU, najmä smerníc EU v právnom priestore členského štátu, Slovenskej republiky. Je teda možno súhlasit's tým, že sféra spoločenských vztahov „práva prostá“ sa existenciou práva EU v priestore členského štátu stáva pomerne útlou, no pozitívny záväzok štátu zákonom upravovat’ priestor ústavne garantovaných základných práv a slobôd tým nie je oslabený.

Vzt’ah jednotlivca ako nositel’a základných práv a slobôd a štátu ako adresáta a garanta základných práva a slobôd jednotlivca, je vzájomný, komplementáry. Je však jednoznačné, že hmotnoprávne vymedzenie základných práv a slobôd bez ústavnej perfekcie možnosti procesného uplatnenia základného práva a slobody jednotlivcom voči štátu, spôsobuje vo vzájomnosti vzt’ahu jednotlivec a štát nežiadúcu nerovnováhu. V uvedenom kontexte je prezentovaný názor J. Drgonca o obmedzenej procesnej vymožitel'nosti základného práva a slobody z titulu absencie vysvetlenia podstaty doktríny Ústavného súdu Slovenskej republiky o pozitívnom záväzku: „Ústavný súd Slovenskej

28 DRGONEC, J.: Ochrana ústavnosti Ústavným súdom Slovenskej republiky, s. 240.

29 WINTR, J.: Principy českého ústavního práva, s.145. 
republiky doktrínou pozitívneho záväzku implikovaného v Ústave SR vyhodnotil Slovenskú republiku ako štát náležiaci do rodiny moderných demokratických a právnych štátov, ktorý si z tohto titulu uložil povinnost' vydávat' zákony zabezpečujúce dostupnost' a vymožitel'nost' tých práv, ktoré ako základné priznal vo svojej ústave. Za základ tejto ústavou uloženej povinnosti Ústavný súd SR označil čl. 51 ods. 1 ústavy. V Rade Európy, aj v Európskej únii, majú jednotlivci právo požadovat' od štátov, aby voči nim splnili svoje zákonodarné povinnosti v sfére pozitívneho záväzku a ak ich nesplnia, majú právo žalovat' štát za nesplnenie pozitívneho záväzku. Ústavný súd Slovenskej republiky ani slovenská právna teória neuviedla jediný dôvod, pre ktorý pozitívny záväzok, implikovaný v Ústave Slovenskej republiky, má rozdielnu kvalitu od pozitívneho záväzku podl’a úniového práva a preto osoby nemajú právo žiadat pomocou žaloby (technicky vzaté pomocou ústavnej st'ažnosti) od Slovenskej republiky, aby splnila svoj záväzok ustanovený ústavou. Bez uvedenia dôvodov ako samozrejmost' odčlenili pozitívny záväzok Slovenskej republiky, ustanovený ústavou, od práva jednotlivca vymáhat' pred súdom splnenie tohto záväzku, hoci účelom pozitívneho záväzku je práve nastolenie právneho stavu, $\mathrm{v}$ ktorom $\mathrm{k}$ právnemu postaveniu jednotlivca patrí aj právo vymôct' si od štátu prijatie zákona, umožňujúceho dosiahnut' vymožitel'nost' základného práva. “30

Vo vzt’ahu pozitívneho záväzku štátu a čl. 51 ods. 1 ústavy je potrebné poznamenat', že výklad čl. 51 ods. 1 ústavy sa v plynúcom čase v právnom priestore Slovenskej republiky obsahovo menil. Ústavný súd Slovenskej republiky čl. 51 ods. 1 najskôr hodnotil tak, že vo vzt’ahu k zákonodarcovi predstavuje čl. 51 ods. 1 ústavy smernicu, ktorá má povahu odporúčania (II. ÚS 17/95). Obligatórny obsah v podobe pozitívneho záväzku štátu získal čl. 51 ods. 1 ústavy výslovným potvrdením viazanosti Slovenskej republiky Dohovorom o ochrane l'udských práv a základných slobôd, či Dohovorom o právach diet’at’a ústavným súdom v jeho neskoších rozhodnutiach (II. ÚS 8/96, II. ÚS 47/97). V uvedenom kontexte existencie nedogmatického judiciálneho postoja ústavného súdu je potrebné zvýraznit' názor L'. Somorovej, podporujúci rovnakú dôležitost' a hodnotu základných práv a slobôd v zmysle čl. 51 ods. 1 ústavy vo vzt’ahu k ostatným základným právam a slobodám, oproti názoru J. Drgonca, ktorý uvedené práva označuje ako qvaziústavné, s možnými úvahami pro futuro v procese de constitutione ferenda, alebo v procese de contitutione lata. Prezentovaný názor má jednoznačne svoje spoločensko historické odôvodnenie z titulu začlenenia sa Slovenskej republiky do európskeho priestoru, $\mathrm{v}$ prvom rade $\mathrm{v}$ hospodárskej a sociálnej oblasti (vol’ný pohyb tovaru, služieb, osôb, kapitálu), čím je nevyhnutné hospodárske, sociálne a kultúrne práva jednotlivca zbavit’ na vnútroštátnej úrovni nálepky tzv. qvaziústavných práv a ústavne vyslovit' ich jednoznačne rovnoprávny charakter s ostatnými základnými právami a slobodami tak, aby ich nositel' $\mathrm{v}$ dynamicky sa meniacich spoločenských reáliách Slovenska ako súčasti Európskej únie nemal žiadne právne bariéry pri ich uplatňovaní.

Po zhrnutí predošlých konštatácií predkladá článok definičný rozmer pojmu ,,pozitvny záväzok Slovenskej republiky“ ako povinnost' štátu prijat' všetky opatrenia vo sfére

30 DRGONEC, J.: Ústava Slovenskej republiky. Komentár, s. 871. 
tvorby práva i vo sfére aplikácie práva, ktoré plynú zo vzájomného vztahu ,jednotlivec a štát" (horizontálny i vertikálny účinok) a ktoré plynú štátu z medzištátnych zmlúv, právne záväzných aktov EU a z ústavného katalogizovania základných práv a slobôd za účelom zabezpečenia výkonu základných práv a slobôd jednotlivca.

JUDr. PhDr. ThDr. Ferdinand Korn, Ph.D.

Vysoká škola DTI Dubnica nad Váhom, Slovenská republika drfkorn@centrum.sk,korn@dti.sk 